\title{
The Presence of Acidic Polysaccharides and Muramic Acid Phosphate in the Walls of Corynebacterium poinsettiae and Corynebacterium betae
}

\author{
By TERESA DIAZ-MAURIÑO* AND H. R. PERKINS \\ National Institute for Medical Research, Mill Hill, London $N_{7}$ I AA
}

(Received 3 September 1973)

\begin{abstract}
SUMMARY
Wall preparations from Corynebacterium poinsettiae and Corynebacterium betae contained no teichoic acids but phosphate-free polysaccharides were present and were extractable with trichloroacetic acid at $35^{\circ} \mathrm{C}$. The substance from $C$. poinsettiae contained rhamnose, glucuronic acid, galactose, mannose and pyruvic acid (molecular proportions $\mathrm{I}: 2: \mathrm{I}: 0 \cdot 33: 0.35$ ) and that from $C$. betae contained glucuronic acid, rhamnose, fucose and mannose (molecular proportions $\mathrm{I}: 2: 0 \cdot 5$ : $0 \cdot 3$ ). In the former polymer, pyruvic acid appeared to be linked to galactose which was in turn linked to rhamnose. The residual peptidoglycans of these species contained much phosphorus. Some of this was present as muramic acid phosphate.
\end{abstract}

\section{INTRODUCTION}

The wall compositions of species of Corynebacterium have been studied in connexion with taxonomic significance (Cummins, 1962). Several plant-pathogenic species did not conform to the arabinose-galactose pattern of animal pathogens, and later the amino acid constituents of the peptidoglycan component were also found to be abnormal (Perkins \& Cummins, 1964; Perkins, 1965). We have now studied in greater detail the non-peptidoglycan components of the isolated walls of two species.

\section{METHODS}

Preparation of the wall. Corynebacterium poinsettiae NCPP 177 and Corynebacterium betae NCPP 373 were grown at $30{ }^{\circ} \mathrm{C}$ in the casein hydrolysate medium CY (Novick, 1963) supplemented with $\mathrm{I} \%(\mathrm{w} / \mathrm{v})$ of glucose. Bacteria were harvested at $2{ }^{\circ} \mathrm{C}$ and suspended in distilled water, and the walls were prepared by differential centrifuging after disruption of the organisms by shaking with glass beads (Ballotini no. 12) in a cell homogenizer (Model MSK, B. Braun, Melsungen, Germany). The autolytic enzymes were inactivated by heating the suspension at $60{ }^{\circ} \mathrm{C}$ for 5 to $10 \mathrm{~min}$. The walls were suspended in $0.05 \mathrm{M}$-sodium phosphate buffer, $\mathrm{pH} 7 \cdot 6$, digested with trypsin ( $\mathrm{I} \mathrm{mg} / \mathrm{ml}$ ) at $37{ }^{\circ} \mathrm{C}$ overnight and then washed several times with distilled water. The trypsin-digested walls were subsequently treated with pepsin $(0.5 \mathrm{mg} / \mathrm{ml})$ in $0.05 \mathrm{M}-\mathrm{HCl}$ at $37{ }^{\circ} \mathrm{C}$ overnight, then washed twice with $\mathrm{I} \cdot 0 \mathrm{M}-\mathrm{NaCl}$, twice with distilled water and freeze-dried.

Isolation of wall polysaccharide. The following procedures were tried (though only method (iv) proved satisfactory): (I) Walls were mixed with ro to $25 \%(\mathrm{w} / \mathrm{v})$ trichloroacetic acid at $0{ }^{\circ} \mathrm{C}$ and shaken for two or three days. After centrifuging, the supernatant liquid was treated with 6 vol. of ethanol or acetone (Armstrong et al. 1958). (ii) Walls were hydrolysed

* Present address: Instituto de Productos Lacteos, Arganda del Rey, Madrid, Spain. 
with $0.05 \mathrm{M}-\mathrm{H}_{2} \mathrm{SO}_{4}$ at $60{ }^{\circ} \mathrm{C}$ for $3 \mathrm{~h}$ or at $100{ }^{\circ} \mathrm{C}$ for $\mathrm{I} \mathrm{h}$ (Knox \& Hall, I965). After neutralization with saturated aqueous $\mathrm{Ba}(\mathrm{OH})_{2}$ and centrifuging, the supernatant liquid was freezedried. (iii) Walls were extracted with aqueous phenol $(45 \%, \mathrm{w} / \mathrm{v})$ at $60{ }^{\circ} \mathrm{C}$ for $5 \mathrm{~min}$ (Hungerer et al. 1967). After centrifuging, both the aqueous layer and the sediment were dialysed against distilled water and freeze-dried. (iv) Walls were treated with $10 \%(\mathrm{w} / \mathrm{v})$ trichloroacetic acid at $35{ }^{\circ} \mathrm{C}$ overnight. After centrifuging, the supernatant liquid was extracted with ether to remove trichloroacetic acid and the aqueous layer was freeze-dried.

Analytical methods. Glucuronic acid was determined with carbazole (Davidson, 1966) and methylpentoses with cysteine-sulphuric acid (Dische \& Shettles, 1947). Neutral sugars were estimated after acid hydrolysis $\left(2 \mathrm{M}-\mathrm{HCl}, 3 \mathrm{~h}, 100{ }^{\circ} \mathrm{C}\right)$ by microchromatography on Eastman Kodak film 5IIV developed with triphenyltetrazolium as described by Moczar, Schilling \& Robert (1967); the intensities of the spots were measured in the Chromoscan apparatus (M.K.2 Joyce, Loebl \& Co. Ltd, Gateshead, County Durham). $N$-acetylglucosamine was determined as glucosamine by the method of Rondle \& Morgan (I955) after hydrolysis with $4 \mathrm{M}-\mathrm{HCl}$ for $4 \mathrm{~h}$ at $100{ }^{\circ} \mathrm{C}$, paper electrophoresis in $0.25 \mathrm{M}$-formic acid and elution of the glucosamine from the paper. Pyruvic acid was determined with $o$-phenylenediamine in $0.5 \mathrm{M}-\mathrm{HCl}$ (Harbon, Herman \& Clauser, 1968). Phosphorus was measured as described by Umbreit, Burris \& Stauffer (1957). Glucosamine and muramic acid were separated by adsorption of muramic acid to charcoal (Hughes, 1968) and measured by the method of Rondle \& Morgan (1955).

Chromatography and electrophoresis. The paper used was Whatman no. 3 or $3 \mathrm{MM}$. Paper chromatography was done in the following solvents: I. $n$-butanol-acetic acid- $\mathrm{H}_{2} \mathrm{O}$ (67:ro:23, by vol.); 2. $n$-butanol-acetic acid- $\mathrm{H}_{2} \mathrm{O}(4: \mathrm{I}: 5$, by vol.); $3 . n$-butanol-pyridine$\mathrm{H}_{2} \mathrm{O}\left(6: 4: 3\right.$, by vol.); 4. ethyl acetate-acetic acid- $\mathrm{H}_{2} \mathrm{O}(9: 2: 2$, by vol. $) ; 5$. $n$-propanolacetic acid $-\mathrm{H}_{2} \mathrm{O}(5: \mathrm{I}: \mathrm{I}$, by vol.). Paper electrophoresis was at $\mathrm{Io} \mathrm{V} / \mathrm{cm}$ for 2 to $3 \mathrm{~h}$ in the following electrolytes: I. $0.25 \mathrm{M}$-formic acid, $\mathrm{pH}$ I $\cdot 9$; II. acetic acid-collidine- $\mathrm{H}_{2} \mathrm{O}(2 \cdot 65$ : $9 \cdot 10:$ I000, by vol.), $\mathrm{pH} 7$; III. 0.0 I M-sodium phosphate buffer, $\mathrm{pH} \mathrm{6.8;} \mathrm{IV.} \mathrm{0.0} \mathrm{I} \mathrm{M-sodium}$ borate buffer, $\mathrm{pH} 9 \cdot 2$.

The papers were developed with alkaline $\mathrm{AgNO}_{3}$ for detection of sugars (Trevelyan, Procter \& Harrison, 1950), ninhydrin for amino acids, Schiff reagent for glycols (Buchanan, Dekker \& Long, I950), the reagent of Hanes \& Isherwood (1949) for phosphate, and that of Rydon \& Smith (1952) for acetamido groups. Electrophoresis of the undegraded wall polysaccharide was carried out on strips of cellulose acetate (Oxoid, London) in $0.05 \mathrm{M}$ sodium phosphate buffer, $\mathrm{pH} 6.9$, at $200 \mathrm{~V}$ for $20 \mathrm{~min}$. The strips were developed with $\mathrm{I} \%(\mathrm{w} / \mathrm{v})$ alcian blue in $5 \%(\mathrm{v} / \mathrm{v})$ acetic acid (Herd, I968).

Column chromatography. Undegraded polysaccharide was applied to a column $(39 \times \mathrm{I} \mathrm{cm})$ of Sephadex Gioo (Pharmacia, Uppsala, Sweden), which had been previously equilibrated with $\mathrm{r} \cdot 0 \mathrm{M}-\mathrm{NaCl}$, and was eluted with the same solution. Fractions $(3 \mathrm{ml})$ were collected and uronic acids were determined.

Ultracentrifugation. Ultracentrifugation was carried out in a model E Spinco analytical ultracentrifuge. Polysaccharide ( $10 \mathrm{mg} / \mathrm{ml}$ ) was dissolved in $0.02 \mathrm{M}$-citrate buffer $(\mathrm{pH} 4.25$ ) containing $0 \cdot \mathrm{I} \mathrm{M}-\mathrm{NaCl}$. Sedimentation velocity was measured in a capillary-type synthetic boundary cell. Molecular weights were determined by the method of Yphantis (1960).

Action of phosphatase on the wall products. The presence of a phosphomonoester in wall products was detected by incubation with a solution of alkaline phosphomonoesterase (enzyme from Escherichia coli, Sigma (London) Ltd, Kingston-upon-Thames, Surrey, Io $\mathrm{mg} / \mathrm{ml}$ ) in $0.2 \mathrm{M}$-ammonium carbonate $(\mathrm{pH} \mathrm{8.4})$ for $\mathrm{I} 6 \mathrm{~h}$ at room temperature, followed by measurement of inorganic phosphate. 


\section{RESULTS}

Composition of the walls of Corynebacterium poinsettiae and Corynebacterium betae

Treatment of the wall of Corynebacterium poinsettiae and $C$. betae with aqueous trichloroacetic acid at $0^{\circ} \mathrm{C}$ did not solubilize any polymer. Hydrolysis with dilute sulphuric acid or treatment with phenol-water extracted from the wall only a small amount of polymer, which was contaminated with amino acids and amino sugars from the peptidoglycan. By extraction of the walls of both species with $10 \%(\mathrm{w} / \mathrm{v})$ trichloroacetic acid at $35{ }^{\circ} \mathrm{C}$ polysaccharides were obtained practically free of the peptidoglycan components. They accounted for $50 \%$ of the weight of the wall and contained no detectable phosphate. Neither micro-organism contained wall teichoic acids, since no glycerol or ribitol could be detected in hydrolysates of the walls.

\section{Homogeneity of the polysaccharide from Corynebacterium poinsettiae}

The polysaccharide appeared to be homogeneous by the following criteria:

(i) Ultracentrifugation. The material gave a sedimentation coefficient $\left(s_{20, w}\right)$ of $\mathrm{I} \cdot 28 \mathrm{~S}$ when the partial specific volume (v) was taken as 0.63 , and was monodisperse after $3.5 \mathrm{~h}$ centrifuging at $59700 \mathrm{rev} . / \mathrm{min}$. The apparent molecular weights at concentrations of 0.64 , 0.42 and $0.21 \%$ were measured at two speeds (20410 and $27690 \mathrm{rev} . / \mathrm{min})$ at $32 \mathrm{~min}$ intervals, beginning $90 \mathrm{~min}$ after reaching speed. Five photographs were taken at different times. The results at any particular concentration showed no significant dependence on time or speed and were therefore averaged. This procedure gave the apparent molecular weights as IO O00, 10900 and $\mathrm{I} 2300$ at $0.64,0.42$ and $0.21 \%$ respectively, i.e. there was some dependence on concentration.

(ii) Gel filtration. Only one component was detected after filtration through Sephadex Gioo, with a peak at $19 \mathrm{ml}$ of eluent. The void volume of the column was $12 \mathrm{ml}$. This component contained all the chemical components of the untreated polysaccharide.

(iii) Electrophoresis. A single anionic band was detected with alcian blue when the polysaccharide was run at $\mathrm{pH} 6 \cdot 9$ on cellulose acetate electrophoresis.

\section{Composition of the polysaccharide from Corynebacterium poinsettiae}

By hydrolysis of the polysaccharide with $2 \mathrm{M}-\mathrm{HCl}$ at $100{ }^{\circ} \mathrm{C}$ for $3 \mathrm{~h}$ followed by chromatography in solvents I, 2, 3 and 4 and electrophoresis in buffers I and II, the following sugars were identified as main components: rhamnose, glucuronic acid, galactose and mannose. Traces of glucose were also found. By quantitative microchromatography in solvent 5 the proportions of rhamnose-glucuronic acid-galactose-mannose were $\mathrm{I}: 2: \mathrm{I}: 0 \cdot 33$. The amount of glucuronic acid relative to the other sugars was also determined with the carbazole reagent with the same result.

After, but not before, partial hydrolysis of the polysaccharide with $0.5 \mathrm{M}-\mathrm{HCl}$ at $100{ }^{\circ} \mathrm{C}$ for $15 \mathrm{~min}$, material giving the Elson-Morgan reaction for $\mathrm{N}$-acetylhexosamines was released. Paper chromatography in solvents 2 and 3 yielded a single spot giving a positive reaction for sugar and acetamido groups. In both solvents it coincided with $\mathrm{N}$-acetylglucosamine and upon isolation from the chromatogram and reaction with the Ehrlich reagent (Reissig, Strominger \& Leloir, 1955) gave a chromogen with the same absorption spectrum as that given by $N$-acetylglucosamine under the same conditions. The $N$-acetylglucosamine released was measured and gave a ratio to total rhamnose of $0 \cdot I: I$. This represented virtually the whole of the glucosamine that could be found in a total acid hydrolysate. Thus glucosamine was at most a minor component or could conceivably have been a contaminant. 
After hydrolysis with $\mathrm{r} \cdot 0 \mathrm{M}-\mathrm{HCl}$ at $100{ }^{\circ} \mathrm{C}$ for $3 \mathrm{~h}$ and electrophoresis in buffer 2, a silver nitrate-positive spot was found that moved further towards the anode than glucuronic acid or phosphoric acid and that coincided with pyruvic acid. On chromatography in solvents 2 and 3 the $R_{F}$ value of this component also coincided with pyruvic acid. When the compound was eluted and allowed to react with 2,4-dinitrophenylhydrazine it gave the characteristic absorption spectrum of the 2,4-dinitrophenylhydrazone of pyruvic acid. The extracellular polysaccharide from Corynebacterium insidiosum is known to contain a substituted monosaccharide identified as 4,6-O-(I'-carboxyethylidene)-D-galactose, which on hydrolysis produced pyruvic acid and galactose (Gorin \& Spencer, 1964). When walls of C. insidiosum were suspended in water and heated at $100{ }^{\circ} \mathrm{C}$ overnight in a sealed tube they gave the same silver nitrate-positive spot on electrophoresis in buffer 2 that was observed with the polysaccharide hydrolysate from $C$. poinsettiae. The amount of pyruvic acid residues in the polysaccharide from $C$. poinsettiae was $2.4 \%$, the molar ratio to rhamnose being $0.35: 1$. The known components described here accounted for $88 \%$ by weight of the dry polysaccharide.

\section{Composition of the polysaccharide from Corynebacterium betae}

The same methods of identification and quantitative estimation described for the polysaccharide from Corynebacterium poinsettiae were followed with the polysaccharide from $C$. betae, which also appeared to be a single polymer as judged by gel filtration (where it eluted in the same position as the polysaccharide from $C$. poinsettiae) and electrophoresis on cellulose acetate. The main components were glucuronic acid, rhamnose, fucose and mannose in the proportions $1: 2: 0.5: 0 \cdot 3$ respectively. Traces of glucose and pyruvic acid were also detected.

\section{Identification of muramic acid phosphate}

The walls of both Corynebacterium poinsettiae and $C$. betae contained phosphate. The peptidoglycan that remained after extraction of the wall with $10 \%(\mathrm{w} / \mathrm{v})$ trichloroacetic acid also contained phosphate, but the polysaccharide did not.

To identify the phosphorylated component, peptidoglycan was hydrolysed in $2 \mathrm{M}-\mathrm{HCl}$ for $3 \mathrm{~h}$ at $100{ }^{\circ} \mathrm{C}$. By electrophoresis of the hydrolysate in buffer I two components containing phosphate were identified. One coincided with phosphoric acid and the other was ninhydrin-positive and gave the Elson-Morgan reaction for amino sugar (Partridge, 1948). This compound was isolated by preparative electrophoresis and incubated with alkaline phosphomonoesterase; the products were inorganic phosphate and a hexosamine that coincided with muramic acid both in electrophoresis in buffers I and II and in chromatography in solvents $I$ and 3 . The eluate from the chromatogram after reaction with the Elson-Morgan reagent (Rondle \& Morgan, 1955) gave a chromogen with the same absorption spectrum as that of muramic acid (i.e. the maximum was at $510 \mathrm{~nm}$ and the extinction increased after $24 \mathrm{~h}$ ).

The proportions of muramic acid, glucosamine and phosphate in the wall and peptidoglycan of Corynebacterium poinsettiae and $C$. betae are shown in Table $\mathrm{I}$. The treatment of either the wall or the purified peptidoglycan of $C$. poinsettiae and $C$. betae with alkaline phosphomonoesterase did not release any inorganic phosphate.

\section{Partial acid hydrolysis of the polysaccharide from Corynebacterium poinsettiae}

The isolated polysaccharide was hydrolysed in dilute hydrochloric acid for periods of up to $\mathrm{I} h$. The yield of oligosaccharides appeared to be best when $0.5 \mathrm{M}-\mathrm{HCl}$ was used at $100{ }^{\circ} \mathrm{C}$ for $15 \mathrm{~min}$. A preliminary separation of the product of this hydrolysis by electrophoresis 
Table I. The hexosamine and phosphate contents of walls and peptidoglycan

The values are given in $\mu \mathrm{mol} / \mathrm{mg}$ dry wt and show the range of 3 or 4 estimations.

\begin{tabular}{cllll}
\multicolumn{1}{c}{ Organism } & \multicolumn{1}{c}{ Fraction } & Glucosamine & Muramic acid & Phosphate \\
Corynebacterium poinsettiae & Wall & 0.35 & 0.38 to 0.39 & 0.14 to 0.17 \\
& Peptidoglycan & 0.64 & 0.42 & 0.30 to $0.4 \mathrm{I}$ \\
Corynebacterium betae & Wall & 0.28 & 0.32 to 0.34 & 0.26 to $0.3 \mathrm{I}$ \\
& Peptidoglycan & 0.68 to 0.74 & 0.40 & 0.58 to 0.70
\end{tabular}

in buffer II yielded neutral and acidic components. The neutral material was fractionated by chromatography in solvent 3 and in addition to free rhamnose it contained galactose, mannose and $\mathrm{N}$-acetylglucosamine, and an oligosaccharide that ran with $\mathrm{N}$-acetylglucosamine in solvent 3 but separated from it in solvent I. On further hydrolysis the oligosaccharide gave rhamnose and galactose in equimolecular proportions. The acidic material isolated after electrophoresis gave three components during chromatography for $48 \mathrm{~h}$ in solvent 3 . The slowest hardly moved from the origin and contained all the sugars of the complete polysaccharide. The second component yielded only galactose and pyruvic acid on further hydrolysis. The fastest-moving component contained galactose, pyruvic acid, rhamnose and glucuronic acid. The results indicate that, as in other organisms, at least some of the pyruvic acid is linked to galactose, which in turn is joined to rhamnose.

In some experiments aqueous solutions of the acidic polysaccharide were allowed to autohydrolyse at $100{ }^{\circ} \mathrm{C}$ for periods of $\mathrm{I}$ to $3 \mathrm{~h}$. In each case the only products of small molecular weight were pyruvic acid and galactose. This result implies that at least some of the galactose residues were present as non-reducing terminals.

\section{DISCUSSION}

The extracellular acidic polysaccharides of some plant-pathogenic species of Corynebacterium contain galactose, glucose and fucose and acidic groups attributable to pyruvic acid present as a carboxyethylidene group (Gorin \& Spencer, I96I, I964). The present work shows that the walls of Corynebacterium poinsettiae contain a somewhat similar polysaccharide, which is covalently linked to the peptidoglycan component. The latter is remarkable for its high phosphorus content, some of which could be isolated as muramic acid phosphate. None of the phosphorus was released as teichoic acid by acid extraction and no evidence for the presence of glycerol or ribitol could be obtained. It seems probable that the polysaccharide was linked glycosidically to some of the phosphate residues, as proposed for Lactobacillus casei (Knox \& Hall, 1965). Whereas the polysaccharide from $L$. casei was released by hydrolysis in $0.05 \mathrm{M}$-sulphuric acid at $60{ }^{\circ} \mathrm{C}$ within a few hours, this treatment had little effect on the walls of C. poinsettiae. However, the linking sugar in L. casei was a hexosamine, as also in the rapidly released teichuronic acid of Bacillus licheniformis (Hughes, 1970), whereas in the polysaccharide from the walls of $C$. poinsettiae only a little hexosamine was present, none of which gave Elson-Morgan chromogen in unhydrolysed samples.

Since their original description in seaweed polysaccharide (Hirase, 1957), carboxyethylidene and other alkylidene groups have been observed in many exocellular microbial polysaccharides, for example: Xanthomonas campestris, Sloneker \& Orentas (1962); Klebsiella rhinoscleromatis, Wheat, Dorsch \& Godoy (1965); and Salmonella typhimurium, Escherichia coli and Aerobacter cloacae, Garegg, Lindberg, Onn \& Sutherland (197I). The proportion of pyruvic acid found in the wall polysaccharide of Corynebacterium poin- 
settiae $(2 \cdot 4 \%, \mathrm{w} / \mathrm{w})$ was comparable with the amounts found in other bacterial products. However, under similar growth conditions $C$. betae elaborated a related wall polysaccharide that contained only traces of pyruvic acid.

The preliminary results on the structure of the polysaccharide from Corynebacterium poinsettiae suggest that, as in the products of other organisms, the pyruvic acid is linked to galactose, and that some of the galactose is present as non-reducing terminals. This resembles the structure proposed for a mucoid from Salmonella typhimurium (Garegg, Lindberg, Onn \& Holme, 1971).

We are indebted to Dr P. A. Charlwood for the ultracentrifugal analysis. T. D.-M. thanks the Fundacion 'Juan March' for a Fellowship.

\section{REFERENCES}

Armstrong, J. J., Baddiley, J., Buchanan, J. G., Carss, B. \& Greenberg, G. R. (I958). Isolation and structure of ribitol phosphate derivatives (teichoic acids) from bacterial cell walls. Journal of the Chemical Society, 4344-4354.

Buchanan, J. G., Dekker, C. A. \& Long, A. G. (1950). The detection of glycosides and non-reducing carbohydrate derivatives in paper partition chromatography. Journal of the Chemical Society, 31623 I 67 .

Cummins, C.S. (1962). Chemical composition and antigenic structure of cell walls of Corynebacterium, Mycobacterium, Nocardia, Actinomyces and Arthrobacterium. Journal of General Microbiology 28, 35-50.

Davinson, E. A. (1966). Determination of uronic acids. Modified carbazole procedure. In Methods in Enzymology, vol. 8, p. 55. Edited by E. F. Neufeld and V. Ginsburg. New York: Academic Press.

Dische, Z. \& Shettles, L. B. (1947). A specific color reaction of methylpentoses and a spectrophotometric micromethod for their determination. Journal of Biological Chemistry 175, 595-603.

GaregG, P. J., Lindberg, B., ONN, T. \& Holme, T. (1971). Structural studies on the M-antigen from two mucoid mutants of Salmonella typhimurium. Acta chemica scandinavica 25, I I85-1 194.

GaregG, P. J., Lindberg, B., OnN, T. \& Sutherland, I. W. (I97I $b$ ). Comparative structural studies on the M-antigen from Salmonella typhimurium, Escherichia coli and Aerobacter cloacae. Acta chemica scandinavica 25, $2103-2108$.

Gorin, P. A. J. \& SPENCER, J. F. T. (I96I). Extracellular acidic polysaccharides from C. insidiosum and other Corynebacterium spp. Canadian Journal of Chemistry 39, 2274-228I.

Gorin, P. A. J. \& SPENCER, J. F. T. (1964). Isolation of 4,6-0-(I'-carboxyethylidene)-D-galactose from the exocellular polysaccharide of Corynebacterium insidiosum. Canadian Journal of Chemistry 42, I230I 232 .

Hanes, C. S. \& Isherwood, F. A. (1949). Separation of the phosphoric esters on the filter paper chromatogram. Nature, London $\mathrm{r64}$, I $107-1112$.

Harbon, S., Herman, G. \& Clauser, H. (1968). Quantitative evaluation of $O$-glycosidic linkages between sugars and amino acids in ovine submaxillary gland mucoprotein. European Journal of Biochemistry 4, $265-272$.

HeRD, J. K. (1968). Identification of acid mucopolysaccharides by micro electrophoresis. Analytical Biochemistry 23, I $17-12 \mathrm{I}$.

HIRASE, S. (1957). Chemical constitution of agar-agar XIX. Pyruvic acid as a constituent of agar-agar I. Identification and estimation of pyruvic acid in the hydrolysis of agar. Bulletin of the Chemical Society of Japan 30, 68-70.

Hughes, R. C. (1968). The cell wall of Bacillus licheniformis N.C.T.C. 6346. Composition of the mucopeptide component. Biochemical Journal ro6, $4 \mathrm{I}-48$.

Hughes, R. C. (1970). The cell wall of Bacillus licheniformis N.C.T.C. 6346. Linkage between the teichuronic acid and mucopeptide components. Biochemical Journal 1r7, 431-439.

Hungerer, D., JANN, K., JaNN, B., ØrSKov, F. \& ØrSKov, I. (1967). Immunochemistry of K antigens of Escherichia coli 4. The K antigen of E. coli 09: K30:HI2. European Journal of Biochemistry 2, I I 5-I 26.

Knox, K. W. \& HALl, E. A. (1965). The linkage between the polysaccharide and mucopeptide components of the cell wall of Lactobacillus casei. Biochemical Journal 96, 302-309. 
Moczar, I. J. M., Schilling, G. \& Robert, L. (I967). A rapid micro-determination of neutral sugars and aminosugars in glycopeptides by thin-layer chromatography. Journal of Chromatography 3I, 56I-564.

Novick, R. P. (1963). Analysis by transduction of mutations affecting penicillinase formation in Staphylococcus aureus. Journal of General Microbiology 33, $12 \mathrm{I}-\mathrm{I} 36$.

PARTRIDGE, S. M. (1948). Filter paper partition chromatography of sugars. I. General description and application to the qualitative analysis of sugars in apple juice, egg white and foetal blood of sheep. Biochemical Journal 42, 238-250.

Perkins, H. R. (I965). Homoserine in the cell walls of plant pathogenic Corynebacteria. Biochemical Journal 97, 3-50.

Perkins, H. R. \& Cummins, C. S. (I964). Ornithine and 2,4-diaminobutyric acid as components of the cell walls of plant pathogenic Corynebacteria. Nature, London 20r, I105-I 107.

Reissig, J. L., Strominger, J. L. \& Leloir, L. F. (I955). A modified colorimetric method for the estimation of $N$-acetylamino sugars. Journal of Biological Chemistry 217, 959-966.

Rondle, C. J. M. \& Morgan, W. T. J. (I955). The determination of glucosamine and galactosamine. Biochemical Journal 6r, 586-589.

Rydon, H. N. \& SMITH, P. W. G. (1952). A new method for the detection of peptides and similar compounds on paper chromatograms. Nature, London 169, 922-923.

Sloneker, J. H. \& Orentas, D. G. (I962). Pyruvic acid, a unique component of an exocellular bacterial polysaccharide. Nature, London r94, 478-479.

Trevelyan, W. E., Procter, D. P. \& Harrison, J. S. ( I950). Detection of sugars on paper chromatograms. Nature, London 166, 444-445.

Umbreit, W. W., Burris, R. H. \& Stauffer, J. F. (1957). In Manometric Techniques, 3rd edn, p. 272. Minneapolis: Burgess Publishing.

Wheat, R. W., Dorsch, C. \& Godoy, G. (1965). Occurrence of pyruvic acid in the capsular polysaccharide of Klebsiella rhinoscleromatis. Journal of Bacteriology 89, 539.

YPHANTIS, D. A. (1960). Rapid determination of molecular weights of peptides and proteins. Annals of the New York Academy of Sciences 88, 586-60I. 